\title{
Pemahaman Konsep Minyak Bumi Hasil Pembelajaran Menggunakan Model Kooperatif Tipe SQ3R Di SMA Negeri 4 Palangka Raya Tahun Ajaran 2017/2018
}

\author{
Anjeli*, Ruli Meiliawati, Abdul Hadjranul Fatah \\ Program Studi Pendidikan Kimia, Jurusan Pendidikan MIPA, FKIP, Universitas \\ Palangka Raya, Indonesia \\ e-mail: anjeliarpin@gmail.com
}

Diterima: 06 Maret 2020; Disetujui: 21 Maret 2020; Diterbitkan: 31 Maret 2020

\begin{abstract}
ABSTRAK
Tujuan penelitian ini untuk mendeskripsikan pemahaman siswa tentang konsep minyak bumi hasil pembelajaran menggunakan model pembelajaran kooperatif tipe SQ3R (Survey-Question-Read-Recite-Review) di SMA Negeri 4 Palangka Raya Tahun Ajaran 2017/2018. Penelitian ini melibatkan siswa kelas XI MIA-3 SMA Negeri 4 Palangka Raya Tahun Ajaran 2017/2018 sebanyak 24 siswa. Instrumen yang digunakan adalah tes pemahaman konsep berupa essay yang Diberikan saat pretes dan postes, lember pengelolaan pembelajran dan angket respon siswa. Data pemahaman konsep siswa diperoleh dari hasil tes tertulis berupa essay yang diberikan sebelum dan sesudah pembelajaran menggunakan model pembelajaran kooperatif tipe SQ3R. Hasil penelitian menunjukkan Rata-rata pemahaman konsep siswa kelas XI MIA-3 SMAN 4 Palangka Raya tahun ajaran 2017/2018 adalah sebesar 84,3 \%.Pemahaman siswa setiap konsep adalah sebagai berikut : (i) sebagian besar siswa $(84,3 \%)$ dapat menjelaskan teori pembentukkan minyak bumi menurut teori Duplex. (ii) Sebagian besar siswa $(89,1 \%)$ dapat menjelaskan komponen-komponen utama minyak bumi. (iii) Sebagian besar siswa $(78,9 \%)$ dapat menjelaskan hasil fraksi minyak bumi yang mempunyai atom C11-C14 dan kegunaannya. (iv) Sebagian besar siswa $(82,2 \%)$ dapat menjelaskan hasil fraksi minyak bumi dengan titik didih terendah dan kegunaannya. (v) Sebagian besar siswa $(88,6 \%$ ) dapat menjelaskan kualitas bensin berdasarkan bilangan oktan. Langkah-langkah model pembelajaran SQ3R yang paling berperan dalam meningkatkan pemahaman konsep siswa adalah pada kegiatan Question, Read and Recite.
\end{abstract}

Kata Kunci: konsep, minyak bumi, pemahaman, $S Q 3 R$.

\section{PENDAHULUAN}

Pendidikan mempunyai arti yang sangat penting dalam kehidupan, baik dalam kehidupan individu, bangsa atau negara. Keberhasilan suatu bangsa terletak pada mutu pendidikan yang dapat meningkatkan kualitas sumber daya manusianya. Pendidikan pada dasarnya suatu proses untuk mambantu manusia dalam mengembangkan dirinya, sehingga mampu menghadapi segala perubahan dan permasalahan dengan sikap terbuka serta pendekatan-pendekatan yang kreatif tanpa harus kehilangan jati dirinya (Soyomukti, 2010).

Kimia merupakan salah satu mata pelajaran pada jenjang pendidikan SMA. Mata pelajaran kimia berisi materi yang erat kaitannya dengan kehidupan sehari-hari sehingga menyenangkan untuk dipelajari. Fakta yang terjadi adalah 
sebagian besar siswa beranggapan bahwa mata pelajaran kimia sulit dipelajari. Hal ini karena pemahaman konsep akademik yang mereka peroleh hanya merupakan sesuatu yang abstrak dan belum menyentuh kebutuhan praktis kehidupan mereka.

Beberapa materi kimia di SMA berisi konsep-konsep yang bersifat abstrak sehingga siswa terkadang kesulitan untuk mempelajarinya. Kesulitan siswa mempelajari materi kimia dapat disebabkan oleh kurangnya minat dan motivasi siswa dalam kegiatan pembelajaran sehingga siswa cenderung pasif, dan tidak mampu menghubungkan antara materi yang mereka pelajari dengan pemanfaatannya dalam kehidupan nyata. Waktu pembelajaran yang terbatas juga dapat menyebabkan tujuan pembelajaran tidak tercapai secara maksimal.

Minyak bumi merupakan salah satu materi yang dipelajari oleh siswa SMA Kelas XI semester genap menurut kurikulum 2013. Materi pokok minyak bumi mencakup teori-teori pembentukkan minyak bumi, komponen minyak bumi, fraksi-fraksi minyak bumi dan pengolahan minyak bumi. Materi ini memerlukan pemahaman konsep lebih dan ketekunan siswa untuk membaca, apabila siswa kurang memahami konsep maka mereka akan kesulitan dalam memahami materi tersebut. Pemilihan serta penggunaan model atau metode mengajar seorang guru memegang peranan penting yang sangat penting yang akan menentukan sukses tidaknya suatu pembelajaran (Hamalik, 2001). Untuk mengatasi permasalahan ini, guru kimia dituntut dapat mengajarkan materi kimia tersebut dengan metode yang tepat agar tujuan yang ingin dicapai dapat terselesaikan dengan sebaik-baiknya. Salah satunya dengan menggunakan model pembelajaran SQ3R (SurveyQuestion-Read-Recite-Review), menurut Robinson model pembelajaran SQ3R merupakan suatu metode pembelajaran yang dirancang untuk meningkatkan prestasi hasil belajar siswa yang mengarahkan siswa lebih aktif dalam membaca pada inti sari atau kandungan-kandungan pokok materi dalam teks sehingga dapat memudahkan siswa dalam mengingat dan memahami apa yang mereka baca. Keunggulan model pembelajaran SQ3R ini diantaranya adalah lebih melibatkan siswa secara langsung dan aktif dalam proses belajar mengajar, lebih mudah mempersiapkan dan melaksanakannya serta memperkuat daya ingat. Oleh karena itu model pembelajaran SQ3R diyakini dapat meningkatkan pemahaman konsep siswa dan hasil belajar siswa pada materi pokok minyak bumi (Septiyani, 2015).

Hasil penelitian Siti Nur Aina (2012) tentang pemahaman konsep konfigurasi elektron menggunakan metode SQ3R mengungkapkan pemahaman konsep siswa sebelum pembelajaran $58,74 \%$ dan setelah pembelajaran $78,16 \%$. Penelitian Eddy Hizriady Saputra (2011) tentang pengaruh penggunaan model pembelajaran SQ3R pada materi sifat-sifat periodik unsur rata-rata skor siswa diperoleh pada saat postes sebesar $92 \%$ dengan kriteria pemahaman siswa sangat baik.

Penelitian tentang pemahaman konsep telah dilakukan Meiliawati (2019) menggunakan model Discovery Learning. Penelitian ini bertujuan mengkaji, "Pemahaman Konsep Minyak Bumi Hasil Pembelajaran Menggunakan Model Kooperatif Tipe SQ3R (Survey-Question-Read-Recite-Review) Di SMA Negeri 4 Palangka Raya Tahun Ajaran 2017/2018. 


\section{METODOLOGI PENELITIAN}

Penelitian ini termasuk jenis penelitian deskriptif, yaitu penelitian yang dimaksudkan untuk mengumpulkan informasi mengenai status suatu gejala yang ada yakni keadaan, gejala menurut apa adanya pada saat penelitian. Penelitian deskriftif menuturkan dan menafsirkan data yang berkenaan dengan situasi yang terjadi dan dialami sekarang, sikap dan pandangan yang menggejala saat sekarang, hubungan antar variabel, pertentangan dua kondisi atau lebih, pengaruh terhadap suatu kondisi, perbedaan-perbedaan antar fakta dan lain-lain.

Penelitian ini dilaksanakan di SMA Negeri 4 Palangka Raya pada semester II (genap) tahun ajaran 2017/2018 yang beralamatkan jalan Sisinga Maharaja III Palangka Raya. Subjek penelitian ini adalah siswa kelas XI MIA-3 SMA Negeri 4 Palangkaraya Tahun Ajaran 2017/2018 sebanyak 24 siswa.

Prosedur penelitian ini secara garis besar dilakukan melalui beberapa tahap, antara lain tahap persiapan dan tahap pelaksanaan. Penjelasan setiap tahap penelitian tersebut adalah sebagai berikut : Langkah-langkah pada tahapan persiapan meliputi perijinan, observasi sekolah, dan penyusunan instrumen penelitian. Langkah-langkah pada tahap pelaksanaan terdiri atas pelaksanaan pretes, pembelajaran menggunakan model pembelajaran koperatif tipe survey, question, read, recite and review (SQ3R), dan pelaksanaan postes. Teknik pengumpulan data berupa pemahaman konsep siswa, pengelolaan pembelajaran, angket respon siswa masing-masing disajikan dalam Tabel 1.

Tabel 1. Teknik Pengumpulan Data

\begin{tabular}{|c|c|c|}
\hline Data yang Diperoleh & Cara Pengumpulan Data & Instrumen \\
\hline Pemahaman Konsep & $\begin{array}{l}\text { Siswa diberikan tes (pretes } \\
\text { dan postes) untuk } \\
\text { dikerjakan secara individu. }\end{array}$ & Soal tes (pretes dan postes) \\
\hline Pengelolaan pembelajaran & $\begin{array}{l}\text { Aktivitas guru mengajar di } \\
\text { amati oleh dua orang } \\
\text { pengamat. Pengamat } \\
\text { diberikan lembar } \\
\text { pengelolaan pembelajaran. } \\
\text { Penilaian diberikan dengan } \\
\text { menuliskan tanda }(\sqrt{ }) \text { pada } \\
\text { kolom tersedia. }\end{array}$ & $\begin{array}{l}\text { Lembar pengamatan } \\
\text { keterlaksanaan } \\
\text { pembelajaran }\end{array}$ \\
\hline Respon Siswa & $\begin{array}{l}\text { Siswa diberikan lembar } \\
\text { angket respon siswa setelah } \\
\text { pembelajaran selesai } \\
\text { dilaksanakan. }\end{array}$ & Angket respon siswa \\
\hline
\end{tabular}

\section{HASIL PENELITIAN DAN PEMBAHASAN}

Peningkatan pemahaman konsep didasarkan pada data hasil pretes dan postes siswa. Butir soal pada pretes dan postes mewakili konsep-konsep Minyak Bumi, dimana setiap butir soal pretes dan postes memiliki kriteria penskoran dengan jumlah skor maksimum adalah 48. Soal-soal pretes dan postes berjumlah 5 butir soal dalam bentuk esai. Peningkatan pemahaman konsep siswa saat pretes dan postes diperoleh dengan rumus normalitas gain : 


$$
\text { Gain }=\frac{\text { Skor }_{\text {postes }}-\text { Skor }_{\text {pretes }}}{\text { Skor }_{\text {maks. }}-\text { Skor }_{\text {pretes }}} \times \mathbf{1 0 0} \%
$$

Skor menunjukkan sejauh mana kemampuan siswa dalam menjelaskan teori-teori pembentukkan minyak bumi yang ditelusuri pada soal nomor 1 dengan kriteria penilaian pretes dan postes. Pemahaman konsep siswa tentang teori pembentukkan minyak bumi, sebanyak 8 orang siswa mengalami perubahan pemahaman konsep. Siswa dengan kode 13 merupakan salah satu siswa yang mengalami perubahan dari skor 0 ke skor 2. Siswa mengalami perubahan pemahaman konsep setelah pembelajaran menggunakan model pembelajaran kooperatif tipe SQ3R, pada postes siswa menjelaskan teori pembentukkan minyak bumi menurut teori duplex adalah minyak berasal dari organisme laut hewani atau nabati, akibat dari pengaruh waktu, suhu dan tekanan berubah menjadi endapan lumpur dan bintik-bintik minyak sehingga memperoleh skor 2 .

Pemahaman konsep siswa mengalami perubahan setelah mengikuti pembelajaran menggunakan model pembelajaran kooperatif tipe SQ3R yaitu pada saat siswa melakukan Survey pada handout dan pada saat siswa menyusun pertanyaan (question) dimana siswa menyusun pertanyaan yang relevan dengan indikator dan didalam pertanyaan yang tersusun tersebut berisi tentang teori-teori pembentukkan minyak bumi. Siswa membaca handout (Read) untuk menemukan jawaban atas pertanyaan yang tersusun yaitu teori pembentukkan minyak bumi menurut teori duplex adalah terbentuk dari organisme yang mengendap di dasar laut dan akibat pengaruh waktu,temperatur tinggi, dan tekanan, jasad renik tersebut berubah menjadi bintik-bintik minyak, kemudian jawaban tersebut didiskusikan. Siswa menghafal dan memahami jawaban yang ditemukan kemudian dipresentasikan (Recite). Kegiatan Survey, Question, Read dan Recite yang membantu siswa untuk memperoleh konsep sehingga perubahan pemahaman konsep pada siswa ditandai dengan peningkatan skor pada saat postes.

Pemahaman konsep siswa pada indikator 2 dapat dilihat dari jawaban pretes dan postes siswa pada butir soal nomor 2. Skor pada butir soal nomor 2 berada pada rentang $0-2$. Skor menunjukkan tingkat pemahaman konsep siswa untuk menjelaskan komponen-komponen utama penyusun minyak bumi. Pemahaman konsep siswa tentang komponen-komponen utama penyusun minyak bumi, sebanyak 10 orang siswa mengalami perubahan pemahaman konsep. Siswa dengan kode 11 merupakan contoh siswa yang mengalami perubahan skor 0 ke skor 2. Setelah pembelajaran menggunakan model pembelajaran kooperatif tipe SQ3R siswa mengalami perubahan pemahaman konsep. Jawaban pada siswa menjelaskan komponen-komponen utama penyusun minyak bumi adalah golongan alkana, golongan sikloalkana, golongan hidrokarbon aromatik dan senyawa-senyawa lain serta memberikan contoh dari masing-masing golongan secara lengkap sehingga diberikan skor 2.

Perubahan pemahaman konsep siswa terjadi setelah mengikuti pembelajaran menggunakan model pembelajaran kooperatif tipe SQ3R. Pemahaman konsep diperoleh siswa pada saat siswa melakukan Survey pada handout dan pada saat siswa menyusun pertanyaan (question) dimana siswa menyusun pertanyaan yang relevan dengan indikator dan didalam pertanyaan yang tersusun tersebut berisi tentang komponen utama penyusun minyak bumi. Siswa membaca handout (Read) untuk menemukan jawaban atas pertanyaan yang 
tersusun kemudian didiskusikan. Handout materi yang dibaca berisi penjelasan tentang komponen-komponen utama penyusun minyak bumi. Siswa menghafal dan memahami jawaban yang ditemukan kemudian dipresentasikan (Recite). Kegiatan Survey, Question, Read dan Recite yang membantu siswa untuk memperoleh konsep sehingga perubahan pemahaman konsep pada siswa ditandai dengan peningkatan skor pada saat postes.

Pemahaman konsep siswa pada indikator 3 ditelusuri dari jawaban pretes dan postes masing-masing siswa pada butir soal nomor 3. Skor yang diberikan pada butir soal nomor 3 berada pada rentang $0-2$. Skor yang diperoleh siswa menunjukkan sejauh mana pemahaman konsep siswa untuk menjelaskan hasil pemisahan fraksi minyak bumi berdasarkan jumlah atom $\mathrm{C}$ dan kegunaannya. Siswa yang mengalami perubahan pemahaman konsep dari skor 0 ke skor 1,5 adalah sebanyak 9 orang. Saat pretes siswa tersebut tidak menjawab sehingga diberikan skor 0. Saat postes siswa mampu menjelaskan hasil fraksi minyak bumi yang mempunyai atom C11-C14 dan kegunaannya adalah kerosin digunakan sebagai bahan bakar kompor dan bahan bakar pesawat sehingga siswa tersebut diberikan skor 1,5 .

Pemahaman konsep siswa dalam menjelaskan hasil fraksi minyak bumi berdasar kan jumlah atom $\mathrm{C}$ menjadi meningkat setelah mengikuti pembelajaran menggunakan model pembelajaran kooperatif tipe SQ3R, dimana siswa memperoleh pemehaman konsep pada saat siswa melakukan Survey pada handout dan pada saat siswa menyusun pertanyaan (question) dimana siswa menyusun pertanyaan yang relevan dengan indikator dan didalam pertanyaan yang tersusun tersebut berisi tentang hasil fraksi minyak bumi berdasarkan jumlah atom $\mathrm{C}$. Siswa membaca handout (Read) untuk menemukan jawaban atas pertanyaan yang tersusun kemudian didiskusikan. Handout materi yang dibaca berisi penjelasan tentang fraksi minyak bumi berdasarkan atom C. Siswa menghafal dan memahami jawaban yang ditemukan kemudian dipresentasikan (Recite). Kegiatan Survey, Question, Read dan Recite yang membantu siswa untuk memperoleh konsep sehingga perubahan pemahaman konsep pada siswa ditandai dengan peningkatan skor pada saat postes.

Pemahaman konsep siswa pada indikator 4 dideskripsikan dari jawaban butir soal nomor 4 dari setiap siswa. Skor yang diperoleh siswa menunjukkan pemahaman konsep siswa pemahaman konsep siswa dalam menjelaskan hasil pemisahan fraksi minyak bumi berdasarkan kenaikkan titik didih. Pemahaman konsep siswa tentang menjelaskan fraksi minyak bumi berdasarkan kenaikkan titik didih, sebanyak 11 orang siswa mengalami perubahan pemahaman konsep. Siswa pada pretes tidak menjawab sehingga diberikan skor 0. Siswa pada postes menjelaskan hasil fraksi minyak bumi dengan titik didih paling rendah adalah gas dengan suhu dibawah 20 kegunaannya sebagai bahan bakar yang dikenal sebagai LNG dan LPG, sumber hidrogen, dan bahan bakar sintesis senyawa organik. Jawaban siswa tersebut berdasarkan deskripsi pemahaman memperoleh skor 2 .

Perubahan pemahaman konsep siswa terjadi setelah mengikuti pembelajaran menggunakan model pembelajaran kooperatif tipe SQ3R. Pemahaman konsep diperoleh siswa pada saat siswa melakukan Survey pada handout dan pada saat siswa menyusun pertanyaan (question) dimana siswa menyusun pertanyaan yang relevan dengan indikator dan didalam pertanyaan yang tersusun tersebut berisi tentang hasil fraksi minyak bumi berdasarkan 
kenaikkan titik didih. Siswa membaca handout (Read) untuk menemukan jawaban atas pertanyaan yang tersusun kemudian didiskusikan. Siswa menghafal dan memahami jawaban yang ditemukan kemudian dipresentasikan (Recite). Kegiatan Survey, Question,Read dan Recite yang membantu siswa untuk memperoleh konsep sehingga perubahan pemahaman konsep pada siswa ditandai dengan peningkatan skor pada saat postes.

Pemahaman konsep siswa pada indikator 5 dideskripsikan dari jawaban butir soal nomor 5 dari setiap siswa. Skor menunjukkan pemahaman konsep siswa untuk membedakan kualitas bensin berdasarkan bilangan oktan. Pemahaman konsep siswa membedakan kualitas bensin berdasarkan bilangan oktan, sebanyak 14 orang siswa yang mengalami perubahan pemahaman konsep. Saat postes siswa mampu menjelaskan bensin yang kualitasnya baik adalah bensin $\mathrm{B}$ dan menjelaskan kandungan isooktana dan $n$-heptana pada bensin sehingga memperoleh skor 2.

Pemahaman konsep siswa dalam membedakan kualitas bensin berdasarkan bilangan oktan mengalami perubahan setelah mengikuti pembelajaran menggunakan model pembelajaran kooperatif tipe SQ3R yaitu ketika melakukan kegiatan Survey, Question, Read dan Recite. Pemahaman konsep diperoleh siswa pada saat siswa melakukan Survey pada handout dan pada saat siswa menyusun pertanyaan (question) dimana siswa menyusun pertanyaan yang relevan dengan indikator dan didalam pertanyaan yang tersusun tersebut berisi tentang kualiats bensin berdasarkan bilangan oktan. Siswa membaca handout (Read) untuk menemukan jawaban atas pertanyaan yang tersusun kemudian didiskusikan. Siswa menghafal dan memahami jawaban yang ditemukan kemudian dipresentasikan (Recite).

\section{SIMPULAN}

Kesimpulan yang diperoleh dari hasil penelitian dan analisis data yang dilakukan terhadap materi Minyak Bumi hasil pembelajaran dengan menggunakan model pembelajaran kooperatif tipe SQ3R (Survey, question, read, recite, riview) adalah: (1) Rata-rata pemahaman konsep siswa kelas XI MIA-3 SMAN 4 Palangka Raya tahun ajaran 2017/2018 adalah sebesar 84,3 \%. (2) Pemahaman siswa setiap konsep adalah sebagai berikut : (i) sebagian besar siswa $(84,3 \%)$ dapat menjelaskan teori pembentukkan minyak bumi menurut teori Duplex. (ii) Sebagian besar siswa $(89,1 \%)$ dapat menjelaskan komponen-komponen utama minyak bumi. (iii) Sebagian besar siswa $(78,9 \%)$ dapat menjelaskan hasil fraksi minyak bumi yang mempunyai atom C11-C14 dan kegunaannya. (iv) Sebagian besar siswa $(82,2 \%)$ dapat menjelaskan hasil fraksi minyak bumi dengan titik didih terendah dan kegunaannya. (v) Sebagian besar siswa $(88,6 \%$ ) dapat menjelaskan kualitas bensin berdasarkan bilangan oktan. (3) Langkah-langkah model pembelajaran SQ3R yang paling berperan dalam meningkatkan pemahaman konsep siswa adalah pada kegiatan Question dan Read.

\section{DAFTAR RUJUKAN}

Arifin Mulyati, dkk (2009). Strategi Belajar Mengajar Kimia. Bandung: Universitas Pendidikan Indonesia.

Dahar, R. W. (1989). Teori-Teori Belajar. Jakarta : Erlangga. 
Indriyani, Novy. (2016). Pemahaman Konsep Minyak Bumi Pasca Pembelajaran Menggunaan Metode Diskusi Berbantuan Media Gambar Pada Siswa Kelas X-8 SMA Negeri 1 Kurun Tahun Ajaran 2015/2016. Skripsi. Palangka Raya: FKIP UPR.

Kunandar. (2014). Penilaian Autentik (Penilaian Hasil Belajar Peserta Didik Berdasarkan Kurikulum 2013). Jakarta: Rajagrafindo Persada.

Meiliawati, R. 2019. Pemahaman Konsep Sifat Jari-Jari Atom Dan Keelektronegatifan Pada Mahasiswa Pendidikan Kimia Semester IV Tahun Ajaran 2016/2017 Hasil Pembelajaran Menggunakan Model Discovery Learning. Jurnal Ilmiah Kanderang Tingang. 10, 1 (Jun. 2019), 38-45.

Mulyanti, Sri. (2015). Kimia Dasar Jilid 1. Bandung : Alfabeta.

Rusman. (2010). Model-model Pembelajaran. Bandung : Mulia Mandiri Press.

Saputra, Eddy Hizrady (2011). Pengaruh Penggunaan Model Pembelajarn Kooperatif Dengan Strategi SQ3R (Survey-Question-Read-Recite-Review) Terhadap Pemahaman Konsep Siswa Pada Pokok Bahasan Sifat-sifat Periodik Unsur Kelas X SMA Negeri 3 Palangkaraya Tahun Ajaran 2010/2011. Skripsi. Palangka Raya: FKIP UPR.

Shoimin, Aris. (2014). 68 Model Pembelajaran Inovatif dalam Kurikulum 2013. Yogyakarta : AR-RUZZ MEDIA.

Soyomukti, Nurani. (2010). Pengantar Sosiologi. Yogyakarta : AR-RUZZ MEDIA.

Sunarya, Yayan. (2012). Kimia Dasar 2 Berdasarkan Prinsip-prinsip Kimia terkini. Bandung : CV. Yarma Widya.

Sudarmo, Unggul Dan Nanik Mitayani. (2014). Kimia Untuk SMA/MA Kelas XI Peminatan Matematika dan Ilmu-ilmu Alam. Jakarta : Erlangga.

Syah, Muhibbin. (2010). Psikologi Pendidikan. Bandung : PT. Remaja Rosdakarya 